\title{
FROM TRANSCENDENTAL IDEALISM TO TRANSCENDENTAL EMPIRICISM AND BEYOND: KANT, DELEUZE AND FLAT ONTOLOGY OF THE ART
}

\section{A B S T R A C T}

In this paper I will show that the movement from Kant's transcendental idealism to Gilles Deleuze's transcendental empiricism and then to new materialisms and speculative realisms is what enables us to talk about the direct and nonmediated access to the thing in itself (or its dissolution). In other words, it's the change from the conditions of possible experience to the conditions of real experience that made possible current philosophical and theoretical discourses of materialisms and realisms. What is of particular interest for the purposes of this paper is how the change from conditions of possible to real experience relates to the current conceptualizations of art practices. More precisely, I will show how the ontology of art changed, or at least that there perhaps appears paradigmshifting possibility of different aesthetics and ontologies of art, flat ontology being one of them, with the appearance of new materialisms and speculative realisms that were made possible by the change to the conditions of real experience. 


\section{INTRODUCTION}

The following diagram shows various philosophical influences across the landscape of correlationist and non-correlationist thought. ${ }^{1}$ We can see that the most influential thinker is Gilles Deleuze when it comes to the fields of new materialisms, affect theories and speculative realisms, and I would argue that is for a reason although many speculative realists, most notably among them Quentin Meillassoux, are critical of Deleuze's philosophy (according to Meillassoux Deleuze is undeniably one of the correlationists). ${ }^{2}$ As with every diagram, this diagram offers rather impoverished picture of all the influences. For example, I have not connected Heidegger and speculative realisms even although there is clear influence in at least one case. ${ }^{3}$ Moreover, I have clearly separated new materialisms and speculative realisms which warrants some justification since some contemporary philosophers do not make such a difference. ${ }^{4}$

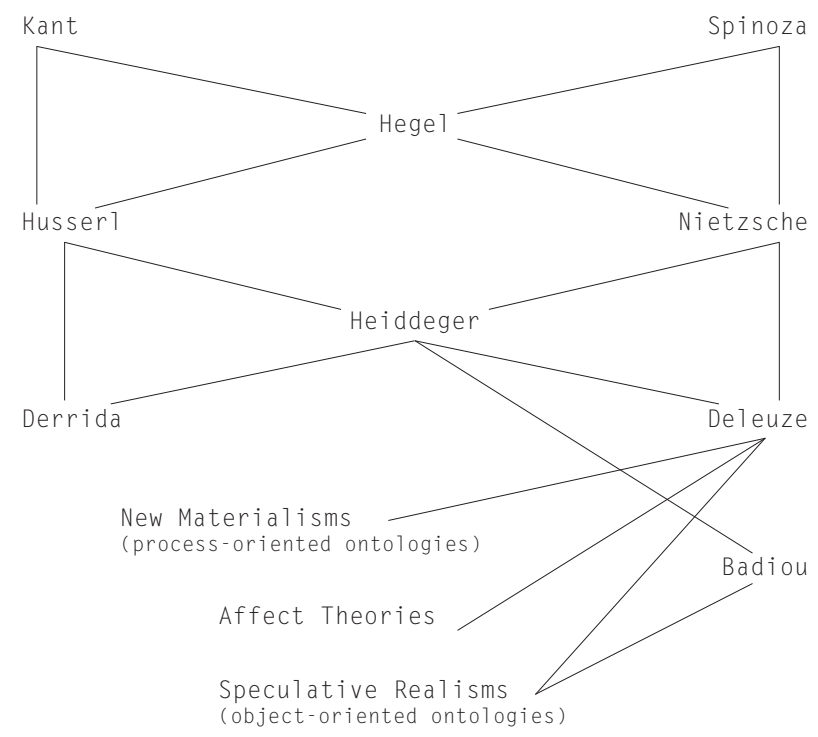

One of the main reasons can be found in the argument offered by Tristan Garcia in his book Form and Object: A Treatise on Things. In a series of illuminating diagrams Garcia shows the differences between three models - substantial, vectorial, and thingly ontology of being. The first model is the model of classical philosophy, of the thing in itself to which predicates, accidents and qualities are ascribed without the thing in itself changing. The second model is the model according to which the thing is constructed at the intersection of various lines consisting of predicates, accidents and qualities. That is the model of becoming or process-oriented ontologies. The third model is the 
model of Garcia's tingly ontology, but which can be generalized to encompass the whole of contemporary object-oriented field of thought. Namely, this aim is to develop an ontology or "to conceive of a model that is neither too strong nor too weak, and to represent things that are really in the world without being in themselves". 5 The first model, which is substantialist, "tends to compact being in the final stage of its process, overdetermining self-saturated things or things in themselves", while the second model of process-oriented ontologies "tends to dissolve and disseminate being, and transforms things into effects, illusions, or secondary realities". ${ }^{6}$ We can now see how process-oriented ontologies and object-oriented ontologies differ. The first ones are philosophies of becoming, which accentuate the change and the flux of qualities, and which are most clearly influenced by Deleuze but also Whitehead, Bergson and Spinoza. The latter ones are philosophies which try to preserve some stability without falling into the trap of positing the thing in itself, the model critiqued by both processoriented and object-oriented ontologies.

\section{KANT AND THE CONDITIONS OF POSSIBLE EXPERIENCE}

Kant's project of transcendental idealism is based on division between the noumenal and the phenomenal, that is, on division between the transcendental and the empirical. Transcendental idealism is a philosophy that deals with the critique of pure reason, or more precisely with the pure theoretical reason (which is directed towards the nature) and pure practical reason (which is directed towards the morality). On the other hand, pure theoretical reason appears as pure understanding (the condition for knowledge of nature), and pure reason in strict sense (the dialectical reason which produces paralogisms and antinomies when disconnected from the empirical). The critique of this pure reason in strict sense is based on transcendental logic (comprised of transcendental dialectic and transcendental analytic) and transcendental aesthetic. Transcendental aesthetic together with transcendental analytic gives us the conditions of all possible experience since the conditions are $a$ priori and transcendental and thus unconnected to the contingency of the empirical. Transcendental aesthetic deals with the space and time as pure forms of sensibility since neither concept can originate from the empirical but serve as necessary a priori forms for the possibility of all external and internal phenomena. Transcendental analytics deals with the pure concepts of pure understanding (quantity, quality, relation and modality), and between the pure concepts of pure understanding and the empirical data that appear under the forms of space and time there are the schemes of imagination that connect them. Pure concepts are always connected to the empirical through the imagination, but if they are applied "purely" they produce transcendental ideas 
such as absolute unity of the thinking subject, absolute unity of the conditions of the phenomena and the absolute unity of all the objects of thinking. Critique of Pure Reason as its purpose had to limit the over-reaching of the pure reason and to try to tie its workings to the empirical. By doing that, however, Kant introduced the notion of the thing in itself (Ding an sich) since all of our knowledge depends on the application of pure concepts of pure understanding to the empirical. While we know that there is something beyond those pure concepts we will never know what that is. ${ }^{7}$ All we can know are phenomena, while the noumena is beyond our reach. Moreover, all of the phenomena are conditioned by the a priori, transcendental laws governing our experience. While we can never know the noumena, what we can know are conditions of all possible experience and thus recognize ourselves as sovereign subjects.

The road to recognizing ourselves as sovereign subjects that are free to give the laws to ourselves is torturous one and proceeds via art. Namely, there is a gap between the pure understanding directed toward the nature and the practical reason directed toward the morality. That gap has to be bridged and it is the judgment that acts as a connection. It is the power of judgment that connects the representations of how the world is objectively constituted and how it should be. The power of judgment enables us to see the nature like it is governed by certain empirical laws, to create aesthetic judgments, to think that organisms are objectively purposive and that the nature as a whole possesses a purpose. The art plays particular role within this system because it enables the production of aesthetic judgment, which possesses four moments. The first moment is the moment of disinterestedness, which means that judgments regarding any artwork are devoid of any practical interest, where interest is defined as a connection to the real desire and acting upon it. The second moment is the universality of aesthetic judgments, which means that the beauty is the real characteristic of the artwork and that the others necessary agree upon that characteristic. The third moment of the aesthetic judgment introduces the purpose of the artwork and it claims that the artwork has none, whether the purpose is understood as a set of external purposes (what the work should do) or internal purposes (what the work should be). The fourth moment is the moment of the necessity of the aesthetic judgment according to which the necessity is based on the common sense which is the a priori principle of taste. ${ }^{8}$

\section{DELEUZE AND THE CONDITIONS OF REAL EXPERIENCE}

Starting point for developing the concept of the conditions of real experience in Difference and Repetition for Deleuze is the critique of Kant's notion of the common sense based on the model Deleuze calls recognition. Namely, 
"recognition may be defined by the harmonious exercise of all the faculties upon a supposed same object: the same object may be seen, touched, remembered, imagined or conceived... Recognition thus relies upon a subjective principle of collaboration of the faculties for 'everybody' - in other words, a common sense as a Concordia facultatum; while simultaneously, for the philosopher, the form of identity in objects relies upon a ground in the unity of a thinking subject, of which all the other faculties must be modalities". ${ }^{9}$ Common sense is, according to Deleuze, the unity from the point of pure subject, while good sense is the unity and norm from the point of view of empirical self. While "good sense determines the contribution of the faculties in each case, common sense contributes the form of the Same", ${ }^{10}$ and they both constitute two complementary sides of a single image of thought, that is, doxa. Deleuze explodes the doxa of active syntheses (apprehension in intuition, reproduction in imagination and recognition in concepts) by introducing the concept of passive syntheses, which give us the conditions of real experience.

Passive syntheses are based on different conception of intuition and the sensible. Namely, elements of the intuition are found in the intensities not in the qualities of the recognized object, intensity is the limit of intuition which lays beyond both the recognition and common sense, and the intuition is constituted by the differential relations of intensities (forces, according to Deleuze's Nietzsche), while those differential relations constitute the conditions of real experience because the conditions never supersede the conditioned (the cause is in the consequence, according to Deleuze's Spinoza). The common sense and the good sense together with active syntheses break down once the primordial nature of passive syntheses is revealed. The apperception, or the unity of "I think", turns out to be just a reflection of what already exists, which means that it only recognizes the life formed according to the reactive forces of habit and memory. Introducing the passive syntheses as the conditions of the real experience means that the exercise of the faculties becomes disharmonious and they stretch beyond their limits in the forcible encounter with the sensible. These passive syntheses also produce multiplicity of contemplating egos constituting larval subjects of passive self. The first passive synthesis is crucial in the constitution of other aspects of time and, thus, for the constitution of both passive self and active subjectivity. It constitutes the present as "living present" but "it necessarily forms a present which may be exhausted and which passes, a present of a certain duration which varies according to the species, the individuals, the organism and the parts of organisms under consideration". ${ }^{11}$ Key insight in this quote is that there are various durations not only for different species and individuals, but that there are different durations depending on the 
"parts of organisms", that is each and every larval subject or contemplating ego possesses its own duration. This insight also entails certain conception of what organism is, of what the body is and what it can do. Body turns out to be multiplicity of different and differentiating durations that are united only at the level of active syntheses of representational subjectivity.

According to Daniel W. Smith, these conditions of real experience or the principles of sensation (intuition) "would at the same time constitute the principles of composition of the work of art, and conversely it would be the structure of the work of art that reveals these conditions". ${ }^{12}$ The artwork ceases to be the object of harmonious converging of various faculties as well as the object which enables the recognition of the sovereign and free subject. Considering that the intuition is not mere representation of the object, but a violent encounter of disharmonious faculties of multiple bodies with that which is "beyond", the artwork becomes the being of sensation which reveals passive syntheses and, most importantly, the disjunctive synthesis that affirms the divergent series. The artwork, furthermore, reveals the passive self, larval egos and the cracked I, that are hidden below the subject of representation. Art thusly plays a special role in Deleuze's critique of Kant's transcendental idealism. Art as the being of sensation disrupts the doxa of common and good sense, and points toward the real conditions of experience on the plane of immanence.

\section{FLAT ONTOLOGY OF THE ART}

The speculative realist and new materialist philosophies takes up the idea of real conditions of experience as that which allows if not epistemological access to things then at least offers the possibility of ontological access to them. It, furthermore, insists in all its philosophical and theoretical forms on the immanence, that is, on a single plane on which all things exist and become. I offer the following comparison between Kant, Deleuze (and most process oriented ontologies inspired by him), and speculative realist or object-oriented philosophies in the following table:

\begin{tabular}{ccc}
\hline KANT & DELEUZE & FLAT ONTOLOGY \\
\hline Being & Becoming & Beings \\
\hline Transcendence & Immanence & Immanence \\
\hline Transcendental & Virtuality & Realism \\
\hline
\end{tabular}


The comparison encompasses three key features of each approach - the question of being, the question of the way the being is, and the question of conditions of access to the being. The being (l'être) is transcendent in Kant, and the only way we can access it is via the transcendental, that is, through our a priori and pure concepts. In Deleuze, being becomes becoming (devenir) on the plane of immanence while the virtual conditions the real experience. In most object-oriented philosophies (OOO), being is replaced with beings (l'étant) while keeping the concept of immanence (the flatness from the title of this paper), and the access is strictly realist by which I mean that the question of epistemology is put in the brackets, at least temporarily, which allows development of ontology.

For Levi R. Bryant "a realist and materialist theory of art would begin with the suspension of the signifying potentials of art and would start with the recognition that works of art are real material beings in their own right". ${ }^{13}$ And furthermore "realism in machine-oriented aesthetics is thus not a thesis about the content of a work of art, but about the being of artwork. To be a work of art is to be something: an entity, substance, individual, thing, object, or machine. There is no work of art that isn't materially embodied in some way or another". ${ }^{14}$ Bryant's materialistic conception of being of the artwork differs, as much of object-oriented philosophy, from process-oriented philosophies in its insistence on the independence of the object from relations it may have at any given moment with any other object. ${ }^{15}$ On the one hand, the object is irreducible to its relations, and on the other it carries the potential for rupture with its actual relations. The reason for non-relational conception of the being of the object is to be found in the attempt to salvage the object's potential for movement. According to Bryant, if the being of the object is exhausted in its relations then there would be no movement since movement presupposes a break from the relations. Consequently, the object retains its independence, "some minimal being over and above whatever relations they happen to entertain". ${ }^{16}$ However, this minimal being that is independent from relations does not mean the difference in quality, but it is based on the differences between a virtual and actual dimension, which Bryant calls virtual proper being and local manifestation of object. The proper virtual being does not change, while the local manifestation or object's qualities are subject to change and, moreover, "virtual proper being consists not in qualities or properties, or in local manifestations, but rather in powers, capacities, or affects. The being of an object lies not in whatever qualities it happens to manifest or actualize, but rather in what an object is capable of doing; its affects. Moreover, a quality or property of an object is not something an object has, but something that an object does as a function of the relations into which it enters". ${ }^{17}$ 
Since artwork is something then this ontology of things or objects also implies consequences to the ontology of art and aesthetics. Most importantly, the being of artwork will possess certain independence from all possible and actual relations it may make with any other object. It follows logically then that the artwork is independent of its context and, hence, that the problem of meaning of artwork becomes if not obsolete then secondary. While the meaning comes from the context, given that the work of art is (minimally) independent from the relations it may make, then we can no longer speak of meaning as being intrinsic to the object we call work of art. Instead, Bryant develops machinic aesthetics of art following Deleuze and Guattari. ${ }^{18}$ Artworks as machines, instead of being constituted as and by signs and meaning, operate and produce something. Two main characteristics come to the fore once the art becomes machinic: transcorporeality and pluripotency. The term trans-corporeality names the fact that an art-machine is always already composed of other machines and that all machines act upon each other and influence each other: "A machine is an entity that affects other entities, but that is also affected by those other entities it affects and interacts with". ${ }^{19}$ Pluripotency refers to the non-teological nature of trans-corporeal machinic actualization of an artwork: "The claim that a machine is pluripotent is the claim that is has no fixed function or purpose that defines its being. Functions of machines often become rigid or typified, yet there is always an indeterminacy of functions haunting any machine holding open the possibility of the machine taking on different functions". ${ }^{20}$

This machinic aesthetics of art leads toward the flat ontology in general and art in particular. Flat ontology is ontology of immanence in which there is no the world or the universe, denying at once that there is something that is the origin of everything else, or in other words, denying that there exists something encompassing everything that is in a unity. Furthermore, "flat ontology refuses to privilege the subject-object, human-world relation as either a) a form of metaphysical relation different in kind from other relations between objects, and that $b$ ) refuses to treat the subject-object relation as implicitly included in every form of object-object relation". ${ }^{21}$ And, finally, according to flat ontology "no entity, whether artificial or natural, symbolic or physical, possesses greater ontological dignity than other objects". ${ }^{22}$ Art, and especially contemporary art, needs to be rethought within the ontological frame of object-object relations, and this is the great potential that object-oriented philosophies offer to us for critical approach to the age of contemporaneity. 
As an inspiration for this diagram served the diagram in the following book: Miško Šuvaković, Umetnost i politika: Savremena estetika, filozofija, teorija i umetnost u vremenu globalne tranzicije (Beograd: Službeni glasnik, 2012), 106-107.

See Quentin Meillassoux, After Finitude: An Essay on the Necessity of Contingency, trans. by Ray Brassier (London/New York: Continuum, 2011), 37. However, some authors do not agree with that assessment, for example Steven Shaviro according to who Deleuze's non-correlational philosophy is based on non-intentional and non-cognitive processes which are immanent to being. See Steven Shaviro, The Universe of Things: On Speculative Realism (London/Minneapolis: University of Minnesota Press, 2014), 131-132.

See Graham Harman, The Quadruple Object (Winchester/Washington: Zero Books, 2011).

For example Peter Gratton, who writes about Quentin Meillasoux, Graham Harman, Ian Hamilton Grant, Elizabeth Grosz, Jane Bennett, Ray Brassier, Adrian Johnston, Catherine Malabou and other process and object oriented philosophers and theoreticians under the "speculative realist" label. See Peter Gratton, Speculative Realism: Problem and Prospects (London/New York: Bloomsbery Academic, 2014).

Tristan Garcia, Form and Object: A Treatise on Things, trans. by Mark Allan Ohm and Jon Cogburn (Edinburgh: Edinburgh University Press, 2014), 11.

Ibid.

See Immanuel Kant, Critique of Pure Reason, trans. by Werner S. Pluhar (Indianapolis/Cambridge: Hackett Publishing, 1996), 318-319.

See Immanuel Kant, Critique of Judgement, trans. by James Creed Meredith (Oxford: Oxford University Press, 2007).

Gilles Deleuze, Difference and Repetition, trans. by Paul Patton (London/New York: Continuum, 2001), 133.

Ibid., 134.

Ibid., 77.

Daniel W. Smith, "Deleuze's Theory of Sensation: Overcoming the Kantian Duality," in Essays on Deleuze, Daniel W. Smith (Edinburgh: Edinburgh University Press, 2012), 89.

Levi R. Bryant, "Towards a Machine-Oriented Aesthetics: On the Power of Art," Art+Media: Journal of Art and Media Studies (2014): 24.

Ibid.

For Bryant's own conception of relations independent object ontology see Levi R. Bryant, The Democracy of Objects (Ann Arbor: Open Humanities Press, 2011).

Levi R. Bryant, "Towards a Machine-Oriented Aesthetics," 25.

Ibid., 26.

As well as ontology of machines and media in another book. See Levi R. Bryant, Onto-Cartography: An Ontology of Machines and Media (Edinburgh: Edinburgh University Press, 2014).

Levi R. Bryant, “Towards a Machine-Oriented Aesthetics,” 29.

Ibid.

Levi R. Bryant, Onto-Cartography, 246.

Ibid. 
Bryant, Levi R. The Democracy of Objects. Ann Arbor: Open Humanities Press, 2011.

Bryant, Levi R. Onto-Cartography: An Ontology of Machines and Media. Edinburgh: Edinburgh University Press, 2014.

Bryant, Levi R. "Towards a Machine-Oriented Aesthetics: On the Power of Art." Art+Media: Journal of Art and Media Studies 5 (2014): 21-32.

Deleuze, Gilles. Difference and Repetition, trans. by Paul Patton. London/New York: Continuum, 2001.

Garcia, Tristan. Form and Object: A Treatise on Things, trans. by Mark Allan Ohm and Jon Cogburn. Edinburgh: Edinburgh University Press, 2014.

Gratton, Peter. Speculative Realism: Problem and Prospects. London/New York: Bloomsbery Academic, 2014

Harman, Graham. The Quadruple Object. Winchester/Washington: Zero Books, 2011.

Kant, Immanuel. Critique of Pure Reason, trans. by Werner S. Pluhar. Indianapolis/Cambridge: Hackett Publishing, 1996.

Kant, Immanuel. Critique of Judgement, trans. by James Creed Meredith. Oxford: Oxford University Press, 2007.

Meillassoux, Quentin. After Finitude: An Essay on the Necessity of Contingency, trans. by Ray Brassier. London/New York: Continuum, 2011.

Smith, Daniel W. „Deleuze's Theory of Sensation: Overcoming the Kantian Duality.“ in Essays on Deleuze, Daniel W. Smith, 89-105. Edinburgh: Edinburgh University Press, 2012.

Shaviro, Steven. The Universe of Things: On Speculative Realism. London/Minneapolis: University of Minnesota Press, 2014.

Šuvaković, Miško. Umetnost i politika: Savremena estetika, filozofija, teorija i umetnost u vremenu globalne tranzicije. Beograd: Službeni glasnik, 2012. 


\section{ETIKA STANOVANJA: RANI HRIŠĆANSKI PRINCIPI GRADSKOG ŽIVOTA I URBANE TRANSFORMACIJE \\ Vladimir Mako}

Rad se fokusira na određeno pitanje u vezi etike koja se razvila u ranom hrišćanskom vremenu i njenog uticaja na proces transformacije rimskog urbanog života, navika, funkcije i arhitektonske prakse krajem petog veka i nakon toga.

Složenost ovog pitanja proizilazi iz činjenice da su rani hrišćanski monaški ideali, koji su se brzo razvili u prvim vekovima nove ere, značajno uticali na formiranje svakodnevnih životnih etičkih principa.

Shodno tome, ovi novi principi su promenili postojeće navike u stanovanju, posebno u oblasti javnog života, zahtevajući novi oblik ponašanja od hrišćanskih građana. Ovaj proces je uticao i na idealistički pogled na ono što koncept hrišćanskog grada može biti, i kako se novi oblik etičkog života odražava na nove urbane i arhitektonske strukture.

KLJUČNE REČI: ETIKA, ESTETIKA, GRADSKI ŽIVOT, URBANA TRANSFORMACIJA

\section{UMETNOST, MODERNOST I SKEPTICIZAM \\ Nikola Dedić}

Ovaj rad se bavi problemom odnosa umetnosti i modernosti - naša osnovna teza je da se umetnik u eri modernosti bavi problemom privatnosti. Pojam privatnosti se koristi u Vitgenštajnovom smislu, kao analogija njegovoj teoretizaciji fantazije privatnog jezika. Njegov koncept privatnog jezika je opis povlačenja običnog jezika iz procesa međudruštvenih odnosa i njegove svakodnevne upotrebe; na taj način, fantazija privatnog jezika je vrsta skepticizma. S obzirom na to da je pojam epistemološkog skepticizma povezan sa idejom modernosti (Dekartov, Hjumov, Lokov moderni skeptični predmet), glavni problem za savremenog umetnika je kako da prevaziđe stanje radikalnog skepticizma, odnosno uslov koji Stenli Kavel u Vitgenštajnovom smislu naziva 'metafizička izolacija'.

KLJUČNE REČI: UMETNOST, MODERNOST, SKEPTICIZAM, PRIVATNI JEZIK, OBIČAN JEZIK, LUDVIG VITGENŠTAJN, STENLI KAVEL

OD TRANSCENDENTALNOG IDEALIZMA DO TRANSCENDENTALNOG

EMPIRIZMA I ŠIRE: KANT, DELEZ I RAVNA ONTOLOGIJA UMETNOSTI Andrija Filipović

U ovom radu ću pokazati da pokret od Kantovog transcendentalnog idealizma do Žil Delezovog transcendentalnog empirizma, a zatim do novih materializma i spekulativnih realizma je ono što nam omogućava da razgovaramo o direktnom i ne-posredovanom pristupu stvari u sebi (ili njenom raspadanju). Drugim rečima, to je promena od uslova mogućeg iskustva do uslova realnog iskustva koja su omogućila trenutne filozofske i teorijske diskurse materializma i realizma. Ono što je od posebnog interesa za potrebe ovog rada je kako je promena od uslova mogućeg do stvarnog iskustva povezana sa trenutnom konceptualizacijom umetničkih praksi. Tačnije, ja ću pokazati kako se ontologija umetnosti promenila, ili barem da se možda čini da postoji mogućnost premeštanja paradigme različitih estetika i ontologija umetnosti, gde je ravna ontologija jedna od njih, sa pojavom novih materializma i spekulativnih realizma koji su omogućeni promenom u uslovima realnog iskustva.

KLJUČNE REČI: TRANSCENDENTALNI IDEALIZAM, TRANSCENDENTALNI EMPIRIZAM, RAVNA ONTOLOGIJA,

UMETNOST, KANT, DELEZ

IMPLIKACIJE VATIMOVOG VERWINDUNG-A MODERNIZMA

\section{U ARHITEKTONSKOJ TEORIJI}

\section{Vladimir Stevanović}

U postmodernom dobu, osim novog pristupa arhitektonskoj praksi, dešavaju se značajne promene u bavljenju arhitektonskim pisanjem i to zahvaljujući uplivu postmoderne transdisciplinarne teorije u arhitektonski diskurs. Arhitektonski teoretičari, kritičari i istoričari rado koriste doprinos 
filozofije, političkih nauka, sociologije, teorije umetnosti i književne kritike na polju kategorizacije i interpretacije postmodernih arhitektonskih stilova ili tendencija. Kako formalno-likovni aspekti prestaju da budu ekskluzivni faktor koji konstituiše stil ili tendenciju, dolazi do implementacije tema i paradigmi iz raznih postmodernih teorija, što dovodi do fenomena prevođenja teorije za arhitektonske potrebe. U većini slučajeva teorijski nazori služe kao pokriće u skladu sa kojim teoretičari arhitekture formulišu autorske poetike određenih arhitekata, proglašavaju poželjne modele recepcije njihovih arhitektonskih dela, i formiraju ukupne stavove prema disciplinarnom i društveno-istorijskom kontekstu. Međutim, postaje interesantno kada ista arhitektonska dela jednog ili više arhitekata bivaju na različite načine interpretirana od strane različitih arhitektonskih teoretičara. U tom smislu, rad sagledava ove premise na konkretnom primeru (1) u kome praksu čini Katalonska arhitektura osamdesetih, (2) u kome se ukrštaju ideje de Solà-Moralesa, Rosija i Fremptona, (3) a teorijski obrazac na koji se može fokusirati je Vatimov filozofski koncept Verwindung-a modernizma.

KLJUČNE REČI: VERWINDUNG, SLABA MISAO, MODERNIZAM, POSTMODERNIZAM, FUNDAMENTALIZAM, FRAGMENTARNOST

PITANJE PREDSTAVLJANJA I IDENTITETA IZMEĐU GLOBALIZMA I LOKALIZMA: SLUČAJ PAVILJONA HONG KONGA NA VENECIJANSKOM BIJENALU

\section{Eva Kit Vah Man}

Ovaj rad uzima umetničku instalaciju Li Kita izloženu u paviljonu Hong Konga na Bijenalu u Veneciji 2013. godine, kao studiju slučaja da ilustruje načine na koje dela nude i pomažu sačinjavanje izazvanog Hong Konga i subverziju agresivne i moćno rastuću Kine. Za razliku od 'očigledne' društvene kritike i 'grandioznog' izgleda umetničkih dela izloženih u kineskom paviljonu, Li Kitova umetnička instalacija - "impresionistička kuća” - u Hong Kongovom paviljonu ne samo da izgleda apstraktno, već i svetovno i čak i trivijalno. Pošto je umetnik bio izabran od strane organizatora bez učešća javnosti, ovo je generisalo žestoku javnu raspravu o reprezentativnosti 'Hongkongnosti' ove instalacije. Moja tvrdnja je da je ono što se čini trivijalnim i običnim u Lijevom radu predstavljeno da konstitutiše, a ne prikaže, umetnost nove generacije Hong Konga. To takođe može biti taktika manevarisanja političkim identitetom koji je nametnula Kina Hong Kongu svojim sveprisutnim i pritiskajućim prisustvom. Umetnost Hong Konga ima potencijal da se udalji ili da sumnja u velike narative Kine, da parafraziram reči istoričara umetnosti Dejvida Klarka (1997). Verujem da je motiv međunarodne konferencije "Hong Kong kao metod" decembra 2014. na Univerzitetu u Hong Kongu bio da upotrebom očekivanog destabilizuje i ospori hongkonški "zdravo-za-gotovo" politički identitet i na taj način promoviše raznolikosti i međuazijsku kulturnu dinamiku.

KLJUČNE REČI: UMETNOST INSTALACIJA, HONGKONGNOST, KINESKOST, POLITIKA IDENTITETA, GLOBALIZAM

SAVREMENA KINESKA UMETNOST:

MAOVO NASLEĐE I DANTOOVA DEFINICIJA

Mary Bittner Wiseman

U ovom radu pokušala sam da izvedem tri stvari. Kao prvo, da identifikujem nekoliko tema $\mathrm{u}$ savremenoj kineskoj umetnosti kroz koje pokazuje svoju suštinski socijalna prirodu i svoj robustan materijalizam, karakteristike kojih nema često u zapadnoj umetnosti. Drugo, da ukažem da način na koji je savremena umetnost u Kini postmoderna jete način na koji je i zapadna umetnost, i da potkrepim tvrdnju da koliko god da su teme i nedavna istorija ove umetnosti drugačije od zapadnog pandana, ova umetnost zadovoljava definiciju umetnosti koju je konstruisao Artur Danto, a to je ona koja na fino zaokružuje i širinu i dubinu koncepta umetnosti. Konačno, u poslednjem delu, predstaviću rad jedne žene-umetnika koji se razlikuje od većine skorašnjih kineskih radova i tipičnih radova zapadne umetnost. On se pozicionira na marginama onoga što je umetnost u Kini i što Dantoova definicija obuhvata, istovremeno sugerišući srž umetničke prakse i jedan od načina biti žena. 